\title{
Effective Learning Environment Characteristics as a requirement of Constructivist Curricula: Teachers' Needs and School Principals' Views ${ }^{1}$
}

\author{
Yeliz Temli Durmuş \\ Asst. Prof., Uşak Üniversitesi, Turkey, yeliz.temlidurmus@usak.edu.tr
}

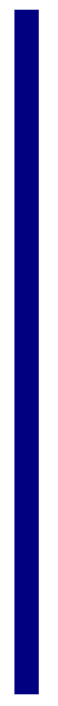

The purpose of this study is to determine elementary school teachers' and school principals' views on physical learning environments of schools where teachers are expected to implement the constructivist philosophy/approach. In this qualitative study, the researcher interviewed 48 elementary school teachers and 6 school administrators working in Uşak, Turkey. The qualitative data were transcribed and analyzed through coding-based content analysis. The data collected from 7 participants ( 5 teachers and 2 administrators) were analyzed by three researchers and the rest were analyzed by the author. At the end of the study, problematic coding was discussed by the same three researchers again and codes were discussed with some $(n=4)$ participants as well. That is, participants' approvals related to the results were obtained from 3 teachers and 1 administrator. The findings showed that teachers' common demands were special classrooms in order to design their classes because they want to implement constructivism. Separate English Language Classrooms with audio-visual materials; Turkish Classrooms with books, visual materials, a computer with projector and internet connection, and bulletin boards; Science and Technology Classes with laboratories, disposable materials and visual materials; Mathematics Classes with smart board, broad storages, and mathematical materials were demanded by the participants.

Key Words: constructivist curricula, constructivist learning environments, school principals' views, teachers' views, learning

\section{INTRODUCTION}

"Only by wrestling with the conditions of the problem at hand, seeking and finding his own solution (not in isolation but in correspondence with the teacher and other pupils) does one learn. "John Dewey, How We Think, 1910.

Ministry of National Education in Turkey determined the constructivism as main approach as a part of centralized curricula. The curricula started to be implemented in 2005 in nation-wide. Since 2009, regardless of the courses in the elementary school curriculum, constructivism and related requirements were presented in

${ }^{1}$ The study was partially presented in IASSR Conference in September 11-14, 2014 in St Petersburg.

URL: http://www.e-iji.net/dosyalar/iji_2016_2_13.pdf

DOI: $10.12973 / \mathrm{iji} .2016 .9213 \mathrm{a}$ 
all curricula offered in the Board of Education web site. Then, these were started to be practiced. In constructivist settings, research is done on interactions with the peers, friends, experts etc. not only in classrooms but also in the community. In other words, transfer of learning as suggested by Vygotsky is a matter of fact when teaching is done for understanding (Graffam, 2003). Briefly, in constructivism, collaboration, group works small group discussions, peer teaching and peer-evaluation, dialog between learners are emphasized (Tenenbaum, Naidu, Jegede, \& Austin, 2001) So as to make meaning, students are in need of interaction with their peers and real world. The teachers take into account students' cognition about the subject to be studied and about the nature of learning. The teacher provides situations that will lead to dissatisfaction with existing ideas in students' mind. The teachers monitor students' understandings, demand for evidence and justification, provide constraints for their thinking, and offer them opportunities to represent their knowledge in a variety of ways. The teacher's role also includes keep learners on task about symbols and phenomena. The teacher then guides and supports students as they make sense of these ideas and tools for themselves in cooperation with their classmates (Driver, Asoko, Leach, Mortimer, \& Scott, 1994; Fosnot, 1996; Tobin \& Tippins, 1993; von Glasersfeld, 1995).

In constructivism, the emphasis is on the learner as a constructer. Especially in social constructivism, the culture and context in understanding events and phenomena in society is emphasized. People construct knowledge based on the culture they live in and social factors (Kim, 2001). From the constructivist perspective, social interaction and language are means to construct knowledge, and thus is shared, rather than an individual experience (Doolittle, 1999). Therefore, it is expected that the physical environment of schools allow learners to interact, cooperate and share opinions with each other. The constructivist approach emphasizes the need for broad places in schools or learning environments to allow for social interaction among learners and enhancement of their physical activities, as well as the availability of various sources and materials that make the learning environment attractive for learners (Sluijsmans and Strijbos, 2010).

Classroom teachers found their pre-service teacher training process ineffective in order to design constructivist learning environment and use constructivism (Aygören \& Saracaloğlu, 2015). As for in-service teacher training programs, insuffient time arranged for training, insufficient content, and limited struggles to reach all of the teachers in a city leads to limitations to implement required aspect of the curricula (Demirkol, 2010). Sluijsmans and Strijbos (2010) highlight teacher training programs to create suitable learning environments and realize constructivist implementations as intended. Creating a suitable learning environment for teachers who attend in-service teacher training programs (Kwakman, 2003), providing them with the opportunity to share their ideas, and piloting new learning strategies together, offering a constructivist learning environment which is critical for the success of constructivist implementations are among the requirement of in-service teacher training programs (Davis, 2002). In the same vein, Marlowe and Page (1998) emphasize the importance of working with other learners and active learning tasks during constructivist based learning process, irrespective of learners' age. The three characteristics of an effective constructivist learning environment are listed as flexibility, accessibility, and usability. Flexibility in 
seating arrangement and study centers, accessibility of materials for the performance of an activity or task, and usability of materials and equipment with clearly established guidelines which is appropriate for learners' age are reported as the foundations of an ideal constructivist learning environment (Michaelis, Grossman, \& Scott, 1975). Similarly, the curriculum specialist Schwab (1973, as cited in Colbert, 2014) underlines the importance of learning environment as the fourth element of education: the learner, the teacher, the subject matter, and the learning environment.

Yanpar (2005) utters material term as an umbrella word including in-school and outschool devices that reflect information and messages. Demiralp (2007) underlines the importance of developing materials for Geography Courses. Similarly, the using of concrete models in mathematics curriculum (Yavuz-Mumcu \& Y1ld1z, 2015) and expensive experiments and activities such as taking photos, trips and observations in Science Curriculum (Sicak \& Arsal, 2013) are stressed. As a part of constructivism, teachers are responsible for using instructional technologies and learning how to use database programs and implement them in courses (Jonassen, Peck \& Wilson, 1999). Innovative use of Information and Communication Technologies (ICT) does not mean uploading all material to software but creating materials that allows student interaction and go beyond that material (Tunal1, 2014). Ellis (2005) puts emphasis on materials and defines future schools with some key characteristics. For example; ICT enabled schools, learner as a researcher who can conduct projects, construction of knowledge, taking on new responsibilities for his own learning, and easily accessible data sources provided by schools. Instructional materials are not pre-determined lists because learners' interest and needs determine the materials, and learning environments celebrates students' interests (Ornstein \& Hunkins, 1998). Each learner has a personal world of experience and creating experiences is vital during learning-teaching process (Ornstein \& Hunkins, 1998). Perkins (1991, as cited in Wilson, 1996) suggests key component for learning environments. Information banks such as videotapes, videodiscs, textbooks; Symbol pads such as database programs, student notebooks; Phenomenaria means areas for presentation, and observations based on the curricula content like aquariums, open museums; Construction kits such as legos, mathematics manipulation software like geometric supporters, authoring tools; Task managers who are generally teachers but learners are co-task managers in constructivist learning environment including computer based instruction programs, assignments in textbooks and assessment devices assumed by teachers.

Uşak was among cities where pilot implementation was realized based on Fatih Project. In other words, pilot implementation of interactive whiteboard and various studies on Fatih Project were conducted in pilot cities. Indeed, students and teachers' views were underlined by ignoring different dimensions and factors, such as twenty-first century skills and curricula, students' attitudes, teachers' perceptions or attitudes (Emre, Kaya, Özdemir \& Kaya, 2011). Constructivism requires using effective instructional technologies and developing materials which are appropriate for attainments, content, learning-teaching process and evaluation components of a curriculum (Aykaç, 2007). 
In constructivism, during the learning-teaching process, learners participate actively in tasks and activities and construct their own knowledge under the guidance of a teacher by engaging in interaction about previous experiences and the new concepts. Learning is defined as a mental process and physical activities, active participation in experiences, and cognitive engagement are necessary for constructive learning (Hein, 1991). Wilson (1996) stresses that constructivist learning environment allows learners to work together and includes various types of resources. Briefly, authentic and real-world environments are found essential for the construction of knowledge (Marsh \& Willis, 2003).

\section{Purpose of the study}

The purpose of the study is to determine elementary school teachers' and school principals' views on learning environments that include physical environments, instructional technologies, materials, and requisites to enable learners to construct knowledge. In this regard, the below 2 questions with two prompt questions were asked to teachers:

(1) How do you evaluate the physical conditions of schools where you work to use constructivism?

1.1. How do you evaluate the physical conditions of classrooms with respect to the use of constructivism?

1.2. What are your basic needs in learning environments for using constructivism?

(2) What are the basic limitations of the learning environment that hinder the use of constructivism?

\section{METHOD}

This study is a qualitative study that aims to provide in-depth information on good learning environments to realize requirements of constructivism from elementary school teachers' and school principals' points of view. In order to reflect the different views about the constructivist learning environments as a requirement of curricula, the socioeconomic status of the locations of elementary schools was considered. Based on the Turkish Statistical Institute Central Population Administration System (TSICPAS, 2007 [MERNIS, 2007]) data, schools in areas of different Socio-Economic Status (SES) in Uşak were listed. In the mentioned data set provided by the TSICPAS, all schools' socio-economic status were listed. Sometimes 2 different elementary schools in a district were shown to be of different socio-economic status. Data were presented under 3 categories: undeveloped level, underdeveloped level and developed level (MERNIS, 2007). In each level, easily accessible 7 elementary schools were selected for sampling in the centre of the city.

The construction of the interview form started with a conceptual framework based on the literature review, and the interview questions were developed by the researcher. After obtaining the opinion of two experts (one professor and one associate professor working on constructivism in the division of curriculum and instruction), some questions were changed. For example, the prospective participants may have not taken any courses including constructivist approach/philosophy during their in-service education. Similarly, they may have not attended an in-service teacher training program including 
the constructivist approach. Because of these possibilities based on expert opinions, the researcher waiting for the completion of pilot study before deciding on two sub questions: 1.a) Could you evaluate your in-service teacher education program with respect to the use of constructivism in the real learning environment?1.b) Could you evaluate your pre-service teacher education program with respect to the use of constructivism in the real learning environment?

A pilot study was realized with two female 21 year experience classroom teachers. Two sub questions mentioned above asked in pilot study. "Could you evaluate your preservice teacher education program with respect to the use of constructivism in the real learning environment?" were not found appropriate for the aim of the study because teachers said "the technological opportunities were very limited when we compare the classes with current classes", "we did not participate in in-service teacher education programs to use constructivism, current materials and equipment. 21 years ago we could not imagine these learning environments. So we cannot evaluate our in-service education". They also underline that only volunteer teachers attend in in-service education and few teachers attend who believe in-service education cannot be effective by reading what they wrote on power point slides. Hence, the sub-question was deleted. After these changes, the form with the semi-structured interview questions was formed. Qualitative data were collected through interviews with forty-eight teachers working in 21 different elementary schools in Uşak, Turkey in the spring term of the 2013-2014 academic year, and the data collection process continued in the fall term of the 20132014 academic year with teachers and school principals. Among 21 school principals, only 6 accepted to participate in the study.

\section{Participants}

After the schools were determined, the researcher intended to interview 2 classroom teachers, 1 foreign language education, 1 science and technology, 1 mathematics, 1 Turkish, and 1 social sciences teacher in each public elementary school. The researcher went to each school and explained the aim of the study to the principals. Some principals rejected the use of a tape recorder; therefore, note-taking was used in some schools. The study was realized with 48 elementary school teachers, of whom 35 were female $(72.9 \%)$ and 13 male $(27.1 \%)$ teachers. In total, 48 public elementary school teachers volunteered to participate in the study. The mean of teaching experience was 18.54 years $(\mathrm{SD}=8.2)$. School administrators were asked to participate in the study as well, and only 6 school administrators accepted. All administrators are male and have $20.40(\mathrm{SD}=3.7)$ years of experience.

Table 1: Teaching fields of the teacher participants $(\mathrm{N}=48)$

\begin{tabular}{lcc}
\hline Teaching field & $F$ & $\%$ \\
\hline Classroom teacher & 17 & 35.4 \\
English teacher & 8 & 16.7 \\
Science and technology teacher & 7 & 14.6 \\
Mathematics teacher & 7 & 14.6 \\
Turkish teacher & 6 & 12.5 \\
Social sciences teacher & 3 & 6.2 \\
\hline \multicolumn{1}{c}{ Total } & 48 & 100 \\
\hline
\end{tabular}




\section{Data Collection and Analysis}

Demographic information was analyzed and reported based on descriptive statistics that included means, standard deviations, and percentages. The qualitative data were collected from public elementary school teachers working in 21 different schools in Uşak. Interviews lasted approximately 20 minutes. Interviews were realized in the teachers' room or school counselors' offices where the participants feel comfortable.

Interviews were transcribed using Microsoft Office word. Then, content analysis was conducted by coding the data for recurrent themes. Firstly the related answers were clustered together, then, the researcher highlighted the coding. Secondly, determination of codes was completed and themes were emerged by constituting related codes clusters. As the third and the last step, themes and codes and transcribed interviews examined by two non-participant researchers who are experts in qualitative research, provided external checks. The most discussed aspect was the difference between "needs" and "wants" for a constructivist learning environment. Because pre-determined list for ideal constructivist learning environment did not exist, the team decided to take participants approval after completing analyze process. In order to minimize threats to theoretical validity, the authors and the non-participant researchers read all of the expressions several times, analyzed data together by discussing unclear expressions until they reached an agreement. Finally, the coding and themes emerged (Maxwell, 1996). Themes were explored with the help of two researchers through negotiations among them. After reaching an agreement, they decided to classify the responses under three main categories (Erlandson, Harris, Skipper, \& Allen, 1993). After that, the researcher went to schools and take participants' approvals and feedbacks on the results. The participants read their codes on transcribed interview document and gave in-detail information to support their ideas. Three teachers and one school principal approved their interviews' codes. They underlined that creative problem solving skills and creativeness of teachers determined their perceptions what is need and what is want. Therefore, all the themes and codes presented under related themes in the study.

\section{FINDINGS}

The results of the study are reported under two category headings, namely, physical environment and limitations to use constructivism. The replies of the participants involved more than one theme category. Therefore, the total number of codes is more than the number of the participants.

\section{Physical Environment}

Teachers underlined the importance of wealth of educational materials. In order to help learners construct their own knowledge, the participants demanded more materials. Especially mathematics teachers (MT) highlighted the importance of materials to give clues on circumference and area. While learning geometry, materials help students to make abstract terms concrete. The mathematics teachers stressed the benefits of smart boards to make abstract terms concrete and provide visual help. However, some teachers stated that they resisted using technological materials because they create anxiety. 
"...I think, each teacher can have a personal classroom in schools. I am a mathematics teacher. My name tag can be hung on the wall and 'Math Class' tag can be written under this. I would like to put some caricatures on the wall. I come across very effective and hortative caricatures" (9 year experienced female Mathematics Teacher).

During data analyze process, the team decided to take the teacher's approval whose expression presented above, on her interview's codes and ask some questions to take in*detailed information: how/why is having a personal classroom related to constructivism? What are the differences between "good learning environment" and "constructivist learning environment" according to her? Her answer was that:

"...First of all, I do not believe in constructivism, I think it leads to unsuccesful implementations. It may be appropriate for private schools or European countries but not for us. Unfortunately, I have to implement constructivist curricula. I cannot teach formulas based on rules of constructivism. Do you believe in I can help students to explore formulas? There is not instructional technology, materials, even if they had provided, I cannot imagine what can I do. What strategy, how it can be implemented? I can bring some materials from my home like pillboxes and ask some questions to students in order to help them figure out characteristics of rectangular prism. Then I can put them on my classroom's cabinets. I may order some geometrical figures to carpenter and put them easily naticable part of my class. In other words, I can analyze my students' needs and try to met these needs if I had seperate math class. If I had, I perceive the responsibity of learning process belong to me, a kind of feeling of belongingness for constructivist implementations"

Science and technology teachers (STT) stressed the absence of laboratories. Actually, in each school a laboratory is available but some of them do not include enough disposable material. Although some laboratories were regular classes, they were designed as a laboratory. Science and technology teachers hesitate to use some materials and equipment because they are registered on the teachers and if they harm these materials, teachers are held responsible for the damage. If they have separate science classrooms and have a chance of designing it as they want, they believe the courses would be more efficient and permanent learning could be achieved more easily. A sink in a science class, science equipment, and visual materials like posters, models and CDs that show dangerous experiments can support teachers' constructivist implementations in the classes.

Similarly, English teachers (ET) want to use visual and audio materials. Like science and technology teachers, English teachers also demand separate English classrooms to hear native speakers' pronunciation by using audio types, listen to children's songs, learn some basic and easy terms by watching cartoons.

“...I wish we had large bulletin boards and we could hang those on the outside wall to show parents what their children do. Exhibition areas might be very 
effective to enhance students' self esteem (7 year experienced female English Teacher)".

During analyzing process, the team decided that this expression needs further explanation. Why bulletin boards needed in particular are asked to participant. She emphazised that the students' English song lyrics wroten by themselves, their caricatures including jokes belongs to English or American cultures, photos from activities can be shown to parents. That motivate learners according to her.

Briefly, the participants underlined the need for separate classrooms for each course. Mathematics teachers demanded separate mathematics classrooms; science and technology teachers also demanded special science classrooms that were equipped with a microscope, visual materials, sink, materials for experiments, and a model of the human body and organs. Although most of the classroom teachers can design their classroom as they want, some classroom teachers cannot because of double shift applications. Double shift means that 2 groups of students take the courses in the same classroom, but one group has class in the morning while the other in the afternoon.

"...Double shift limits us while designing the classroom as we need. In the afternoon I cover the courses, in the morning another teacher covers courses in the same classroom. That's why I cannot change the seating arrangement. If I change it, before leaving the class, I re-arrange seats. This situation limits me to change this back to back seating arrangement" (17 year experienced female Classroom Teacher).

Beside the seating arrangement, classroom sizes were criticized. There is no place for walking, lying and reading books or drawing, searching or creating a learning center like a science learning center, art center in a classroom. Teachers suggest decreasing the number of students in a classroom to create a place for free-time activities. One of the participants stated:

“...I think I am a lucky teacher because my students' parents are very sensitive to the needs of the class. Parents bought a projector, computer, various books for the classroom. The principal promised that he would not change our classroom next year, so the parents want to change curtains as well. If I had the chance, I would like to have a carpeted floor, as early childhood classes have" (9 year experienced female Classroom Teacher).

The above expression belongs to a classroom teacher and the team met for analyzing the data of the current study decided to take her in-detail information and ask some questions to understand her. Why are new curtains and carpets important when implementing constructivism? What makes all these characteristics of physical learning environments typical for constructivism? Her answers underlined that creating an interesting classroom for students is the first step of using constructivism. The second one for students is to feel in safe like their homes. If the activities are conducted on carpet floor, they feel in safe and comfortable learning environment leads to feeling of enthusiasm from her point of view. '...... 'Necessity' does not makes sense for children, it is boring. Enthusiasm and fun are the key components of games. Constructivism means 
playing games for learning for me. In order to create a safety learning environment for children I need carpet floor, intereting and unstrandized curtains and so on"

“...I live in a rural area. I thought we can easily design classes for each course because our class size is acceptable for using constructivism in terms of class size. But the physical conditions of schools are bad. The students who live border villages mobilize here. If we have more materials and educational sources, we can be successful" (5 year experienced female Classroom Teacher).

Teachers also expressed that they need personal cabinets to hold exam papers. As a requirement of constructivism, different types of assessment method and techniques are used. As a result, they complained that their house's rooms are full of exam papers. Teachers expressed their need for personal cabinets. Furthermore, they emphasized the general needs to use constructivism effectively. More bulletin boards in classes and corridors, separate libraries for each course, and large classrooms were among these needs.

Table 2: Learning Environment

\begin{tabular}{rllllll}
\hline \multicolumn{1}{l}{ Coding } & $f$ & & & & & \\
\hline More Equipment and Materials & $C T$ & $E T$ & $S T T$ & $M T$ & $T T$ & $S S T$ \\
visual materials & 13 & 7 & 7 & 4 & 4 & 1 \\
audio materials & - & 5 & 3 & 3 & - & 1 \\
computer & 6 & 4 & 3 & 1 & - & - \\
net connection & 5 & 2 & 2 & - & 2 & 1 \\
CDs & 5 & 2 & 3 & 2 & 1 & 1 \\
Books & 4 & 2 & - & - & 1 & 1 \\
Feeling free to use materials & 5 & 1 & - & - & 1 & 1 \\
personal cabinets & 6 & 3 & 2 & 3 & 1 & - \\
\hline
\end{tabular}

*based on the person who expressed various need was calculated as one expression only for this code.

Table 3: School Physical Environment

\begin{tabular}{lllllllll}
\hline Coding & \multicolumn{1}{c}{$f$} & & & & \\
\hline & & $C T$ & ET & STT & MT & TT & SST \\
\cline { 3 - 8 } $\begin{array}{l}\text { Separate classrooms } \\
\text { teaching fields }\end{array}$ & for different & 2 & 7 & 6 & 4 & - & 1 \\
$\begin{array}{l}\text { More free field } \\
\text { arrangement }\end{array}$ & for & seating & 11 & - & - & - & - & - \\
\begin{tabular}{l} 
Exhibition area \\
\hline
\end{tabular} & & 4 & 1 & 3 & 1 & - & - \\
\hline
\end{tabular}

\section{Schools' Principals Views}

After completing data from the teachers, the findings were analyzed and the results were discussed with the school principals so as to triangulate the data. The results of the triangulation showed that teachers and school principals hold different views. Some 
principals $(n=4)$ had experienced separate classroom design and underlined the limitations of the design. Therefore, the researchers re-defined the participants and added school principals as participants.

As the below quotations explained, school principals hesitate to implement separate classroom design for each course because of financial concerns. Seating arrangement has to design the most crowded classroom and it create financial burden. Satisfying teachers' needs are stressed as another important point.

“...Design the school based on the teaching fields and arranging the classrooms is not logical from an economic perspective. I was working in a public school as school principal in another town in Uşak and for each course we had a separate class and each class assigned to a teacher. We had to arrange each classroom based on the size of the most crowded class. Total number of attendance was very low in some classes while some were high. School principals faced a financial situation" (28 year experienced male school principal).

“...I think satisfying teachers is a very difficult task. If you provide material for one classroom, the other teachers react and demand for another one for their classes. We had only one projector in school and all teachers demand one by citing the other class that has a projector" (27 year experienced male school principal).

One school principal has experience on the separate classroom for each course. He underlined the implementation creates chaos and affect other classes. According to principals, providing instructional technology for each classroom, preparing time allocation schedule are difficult tasks.

“...My school had separated classes based on the classes of the previous academic year. I did not like this implementation because after the bell rang, students ran to the room where the next class took place. Some classes would be continuing. Students had to wait for that class to finish, and would make noise. It is very hard to organize" (15 year experienced male school principal).

\section{CONCLUSION}

Teachers believe that using the constructivist approach in class results in permanent learning. Indeed, in an experimental study conducted by Ünal and Çelikkaya (2009) the results showed that the constructivist approach leads to permanent learning in social studies classes. Similarly, constructivist approach implementation has positive effects on students' success in science classes as well (Saygin, Atılboz, \& Salman, 2006). Teachers believe that using the constructivist approach in class results in achievement.

Participants expressed that teachers are in need of different resources, visual materials and furnishing. Perkins (1991 as cited in Wilson, 1998) underlines the importance of information banks (such as videodisks, encyclopedias), symbol pads (such as drawing programs, notebooks), phenomenaria (instructional simulations, to bring the world to learners) construction kits (such as learning logs) and task managers (such as grading 
programs, assignments within textbooks). Consistent results were obtained in this study. The participants expressed their need to make the content concrete and address students with different skills.

Classrooms and schools' physical inadequateness in terms of storage and exhibition purposes (Kasapoğlu, 2010), materials special to the teaching field, knowledge sources, limitations in changing seating arrangements (Gürol \& Yalçın, 2009) were discussed. Participants from different teaching fields highlighted the same need; they are in need of special classrooms that include specific materials based on the teaching fields. Teachers believe that audio-visual archives, computers, carpets, storage spaces and some other needs can help them implement constructivism effectively.

As Blooser (1999) underlined in his qualitative studies, although teachers are active, students continue their passive roles during learning teaching process, but participants believe that they implement constructivism as curricula suggest in this study. One of the result of the study is that teachers thought students wants to keep their passive roles. In the theory it is a conflict for using constructivism (Vermette \& Foote, 2001). The participants associate this issue with educational policy. Akar (2003) states that classroom seating arrangements do not allow the instructors/teachers to design a Ushaped or O-shaped classroom, and all learners have to look at the teachers as if they are the transmitter of knowledge and smart aleck. The participants stress that because another class start their lessons after the teachers completed the learning process, teachers feel they do not have a right to redesign the classroom seating as they want. This limits their constructivist implementations and therefore teachers demand separate classrooms. Obviously, the participants want separate classrooms, regardless of their subject.

Conducting grounded theory studies with a small sampling is the first suggestion of the study. During the study, the researcher took three participants' in detailed explanations to figure out what they actually say. The major assumption of the study is "the teachers use constructivism and they are constructivist teachers". Because the Ministry of National Education determined the constructivism as the philosophy of the curricula and they are implemented all over the country, using constructivism is perceived as a obligation by teachers. Observations can be made for determinate the differences between ideal curricula and implemented curricula.

Physical environment for constructivist learning is not only the existing equipment in school and around school. People, its community, natural characteristics can be used for constructivist learning. As a limitation of the study, these characteristics were ignored and constitute the limitation of the study.

\section{REFERENCES}

Akar, H. (2003). Impact of constructivist learning process on preservice teacher education students' performance, retention, and attitudes. Unpublished doctoral dissertation, Middle East Technical University, Ankara. 
Aygören, F. \& Saracaloğlu, A. S. (2015). Sınıf öğretmenlerinin yapılandırmacı öğrenme ortamlarına ilişkin görüşleri (Çine İlçesi Örneği). Mehmet Akif Ersoy Üniversitesi Eğitim Fakültesi Dergisi, 34, 194-223.

Aykaç, N. (2007). İlköğretim programında yer alan etkinliklerin öğretmen görüşleri doğrultusunda değerlendirilmesi (Sinop ili örneği). Ahi Evran Üniversitesi Kırşehir Eğitim Fakültesi Dergisi, 8(2), 19-35.

Colbert, J. (2014). Classroom design and how it influences behavior. Early Chilhood News. Retrieved May, 24, 2014 from http://www.earlychildhoodnews.com/earlychildhood/article_view.aspx?ArticleID=413

Davis, K. S. (2002). Change is hard: What science teachers are telling us about reform and teacher learning of innovative practices. Science Education, 87, 3-30.

Doolittle, P. E., (1999). Types of constructivism . Retrieved September 29, 2005, from http://edpsychserver.ed.vt.edu/workshops/tohe1999/ types.html

Demiralp, N. (2007). Coğrafya eğitiminde materyaller ve 2005 coğrafya dersi öğretim programı. Kastamonu Eğitim Dergisi, 15(1), 373-384.

Demirkol, M.(2010). İlköğretim okullarında öğretmenlere yönelik okul temelli hizmetiçi eğitim etkinliklerinin değerlendirilmesi. Milli Eğitim, 188, 158-173.

Emre I, Kaya Z, Ozdemir T.Y \& Kaya ON (2011). Effects of using interactive whiteboard on pre-service science teachers' attitudes toward information and communication technologies and achievement in topic of cell division. 5th international computer and instructional technologies symposium, 22-24 September 2011 Firat University, Elazı̆̆, Turkiye.

Erlandson, D. A. , Harris, E. L., Skipper, B. L., \& Allen, S. D. (1993). Doing naturalistic inquiry. Retrieved October 15, 2012, from http://books.google.com.tr/books?id=mOawndGmMsIC\&printsec=frontcover\&hl=tr\&so urce $=$ gbs_ge_summary_r\&cad $=0 \# v=$ onepage $\& q \& \mathrm{f}=$ false.

Gürol, A. \& Yalçı, H. (2009). İlköğretim programının öğrenci sayısının fazla olduğu siniflarda uygulanmasına ilişkin sorunlar [Problems on implementation of new elementary school curricula in crowded classrooms]. Paper presented at the 8th National Symposium of Classroom Teacher Education, Osmangazi University, Eskişehir.

Hein, G. E. (1991). Constructivist learning theory. Retrieved October 6, 2005, from www.exploratorium.edu/IFI/resources/constructivistlearning.html

Jonassen, D.H., Peck, K.L. \& Wilson, B.G. (1999). Learning with technology: A constructivist perspective. Prentice Hall: NJ.

Kasapoğlu, K. (2010). Relations between classroom teachers attitudes toward change, perceptions of "constructivist" curriculum change and implementation of constructivist teaching and learning activities in class at primary school level. Unpublished doctoral dissertation, Middle East Technical University, Ankara. 
Kim, B. (2001). Social constructivism. Retrieved October 5, 2005, from http://www.coe.uga.edu/epltt/Social Constructivism.htm

Kwakman, K. (2003). Factors affecting teachers' participation in professional learning activities. Teaching and Teacher Education, 19, 149-170.

Marlowe, B. A., \& Page, M. L. (1998). Creating and Sustaining the Constructivist Classroom. CA: Thousands Oak: Corwin Press,

Marsh, C. J., \& Willis, G. (2003). Curriculum: Alternative approaches, ongoing issues (3rd ed.). Upper Saddle River, NJ: Merrill Prentice Hall.

Maxwell, J.A. (1996). Qualitative research design: An interactive approach. Thousand Oaks, CA: Sage

Michaelis, J. U., Grossman, R. H., \& Scott, L. F. (1975). New designs for elementary curriculum and instruction (2nd ed.) New York: McGraw-Hill.

MNE-Ministry of National Education, (2009). National education statistics: formal education: 2008-2009. Ankara: MNE.

MNE-Ministry of National Education, (2010). İlköğretim Program Dosyaları [Primary school Curricula Files]. Retrieved February 17, 2010 from http://ttkb.meb.gov.tr/ogretmen/modules.php?name=Downloads\&d_opTopRated

Saygın, Ö., Atılboz, N. G., \& Salman, S. (2006). The effect of contructivist teaching approach on learning biology subjects: The basic unit of the living things-cell. Gazi Üniversitesi Eğitim Fakültesi Dergisi, 26(1), 56-64

Sluijsmans, D. M. A., \& Strijbos, J. W. (2010). Flexible peer-assessment formats to acknowledge individual contributions during (web-based) collaborative learning. In B. Ertl (Ed.), E-Collaborative knowledge construction: Learning from computer supported and virtual environments (pp.139-161). Retrieved September 17, 2011 from http://issuu.com/daharkedjosappiring/docs/e_collaborative_knowledge_construction

Sicak, A. \& Arsal, Z. (2013). Evaluation of the lesson unit of Let's Learn about the World of Organisms in The Elementary School Fifth-Grade Course of Science and Technology with respect to the educational criticism model. Karaelmas Journal of Educational Sciences, 1, 157-175.

Tenenbaum, G. Naisu, S. Jedege, O.; \& Austin, J. (2001). Constructivist pedagogy in conventional oncampus and distance learning practice: an exploratory investigation. Learning and Instruction, 11, 87-111.

Tunali, S. (2014). Schools of the future in globalized society: forecasting via scenario development method in Turkish schools. Unpublished doctoral dissertation, Middle East Technical University, Ankara, Türkiye.

Ünal, Ç. \& Çelikkaya, T. (2009). The effect of constructivist approach on success, attitude and permanency at the social sciences teaching: 5th class example. Atatürk 
Üniversitesi Sosyal Bilimler Enstitüsü Dergisi, 13(2), 197-212. Retrieved September 21, 2013 from http://e-dergi.atauni.edu.tr/index.php/SBED/article/view/2659/2651

Vermette, P. \& Foote, C. (2001). Constructivist philosophy and cooperative learning practice: Toward integration and reconciliation in secondary classrooms. American Secondary Education, 30(1). 26-37.

Wilson, B. G. (1996). What is a constructivist learning environment? In G. B. Wilson (Ed.), Constructing learning environments: Case studies in instructional design (pp. 3-8). Englewood Cliffs: Educational Technology Publications.

Wilson, B. G. (1998). Constructivist learning environments: Case studies in instructional design. Retrieved December 10, 2013 from http://www.google.com.tr/books?hl=tr\&lr=\&id=mpsHa5f712 wC\&oi=fnd\&pg=PR5\&dq=learning +environment+constructivism\&ots=sXhhBk7TLr\&sig=8el5zRPGI62CfYJyLOZNPqHk1rg\&redi $\mathrm{r} \_$esc $=\mathrm{y} \# \mathrm{v}=$ onepage \&q=learning\%20environment $\% 20$ constructivism\&f=false.

Yanpar, T. (2005). Öğretim Teknolojileri ve Materyal Geliştirme. Ankara: Anı Yayınları.

Yavuz-Mumcu, H. \& Yıldız, S. (2015). Developing, implementing and evaluating of a web-based instructional material supporting spatial thinking. Elementary Education Online, 14(4), 1290-1306.

\section{Turkish Abstract \\ Yapılandırmacı Eğitim Programlarının Gerekleri Doğrultusunda Etkili Öğrenme Ortamları: Öğretmen İhtiyaçları ve Okul Müdürü Görüşleri}

$\mathrm{Bu}$ çalıșmanın amacı, ilköğretim programlarının temelini oluşturan yapılandırmacı felsefenin/yaklaşımın uygulanmasını için gerekli öğrenme ortamlarına yönelik ilköğretim okulu öğretmenlerinin ihtiyaç ve okul müdürlerinin görüşlerini ortaya koymaktır. Bu nitel çalışmada araştırmac1, Uşak ilinde toplam 21 okuldan 48 ilköğretim okulu öğretmeni ve 6 okul müdürü ile görüşme yapmıştır. Kaydedilmiş görüşme kayıtları birebir kâğıda dökülmüş, kodlar oluşturularak içerik analizi yapılmıştır. Toplam 5 öğretmen ve 2 okul müdürünün görüşmeleri 3 araştırmacı tarafından analiz edilmiş, kodlar ve temalar üstünde tartışılmıştır. Bu doğrultuda, tüm kayıtlar kod ve temalar altında bir bütünlük oluşturacak şsekilde analiz edilmiștir. Analiz sürecinin son aşamasında tartışmalı ifadeler ve kodlar, sözü geçen 3 araştırmacı tarafindan tekrar tartışılmış, 4 katılımcının onayı alınmıştır. Bulgular, öğretmenlerin kendi derslerine özel sınıfların oluşturulmasının ortak bir talep olduğunu göstermiştir. Nedeni, kendi sınıflarını, kullanacakları yöntem ve tekniklere uygun tasarlayabilme, kullanacakları materyalleri kalıcı materyaller olarak geliştirip ya da satın alıp kullanabilme isteğidir. İşitsel-görsel materyallerle zenginleştirilmiş bir İngilizce sınıfı, kitaplar, görsel materyallerle zenginleştirilmiş, internet ve projektör bağlantısı olan, aktif öğrenme sonucu çıkan ürünleri sergileyebilecekleri panoları ve sergi alanları olan bir Türkçe sınıfi; laboratuvar içeren, kullanılıp atılabilir materyaller, tehlikeli deneyleri gösterebilmek, sunumları desteklemek ve bilimsel gerçekleri somut olaral gösterebilmek için kullanılabilecek görsel materyallerle desteklenmiş Fen Bilgisi sınıfları; akıllı tahta, dolap gibi geniş depolama alanı ve matematiksel/geometrik materyallerle zenginleştirilmiş Matematik sınıfı öğretmenler tarafından ihtiyaç olarak tanımlanmıştır. Okul müdürleri ise sınıfların en kalabalık sınıfa göre tasarlanmasının ekonomik olmayacağı, dersi biten sınıfın öğrencilerinin, diğer sınıfa 
geçişleri sırasında öğrenme-öğretme sürecini etkilemeleri gibi nedenlerle öğretmenler tarafindan ifade edilen ihtiyaçları olumlu bulmadıklarını belirtmişlerdir.

Anahtar Kelimeler: yapılandırmacı eğitim programları, yapılandırmacı öğrenme ortamları, okul müdürü görüşleri, öğretmen görüşleri, öğrenme

\section{French Abstract}

Caractéristiques d'Environnement d'Apprentissage Effectives comme une exigence de Programmes d'études Constructivistes : les Besoins de Professeurs et les Avis de Principaux Scolaires

Le but de cette étude est de déterminer les avis des enseignants du primaire et principaux scolaires sur les environnements d'apprentissage physiques d'écoles où on attend à ce que des professeurs mettent en œuvre la philosophie/approche constructiviste. Dans cette étude qualitative, le chercheur a interviewé 48 enseignants du primaire et 6 administrateurs scolaires marchant dans Usak, la Turquie. Les données qualitatives ont été transcrites et analysées par l'analyse de contenu à base de codage. Les données rassemblées de 7 participants $(5$ professeurs et 2 administrateurs) ont été analysées par trois chercheurs et le reste a été analysé par l'auteur. À la fin de l'étude, le codage problématique a été discuté par les trois mêmes chercheurs de nouveau et les codes ont été discutés avec certains $(\mathrm{n}=4)$ des participants aussi. C'est-à-dire les approbations des participants liées aux résultats ont été obtenues de 3 professeurs et 1 administrateur. Les conclusions ont montré que les demandes communes des professeurs étaient des salles de classe spéciales pour concevoir leurs classes parce qu'ils veulent mettre en oeuvre le constructivisme. Séparez des Salles de classe de langue anglaise avec des matériels audiovisuels; Salles de classe turques avec livres, matériels visuels, un ordinateur avec projecteur et connexion à Internet et tableaux d'affichage; science et Classes Technologiques avec laboratoires, matériels disponibles et matériels visuels; les classes de Mathématiques avec le conseil intelligent de larges stockages et des matériels mathématiques ont été exigées par les participants.

Mots Clés: programmes d'études constructivistes, constructiviste apprenant environnements, les avis de principaux scolaires, les avis de professeurs, apprentissage

\section{Arabic Abstract}

$$
\text { خصائص بيئة التعلم الفعالة كثرط من البنائية المناهج : احتياجات مديري المدارس وآراء مديري المدارس }
$$

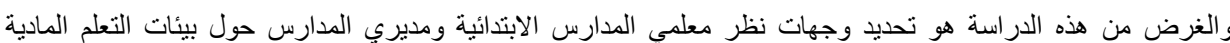

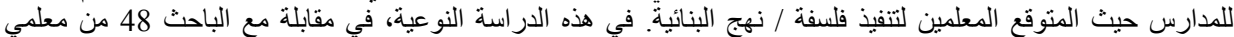

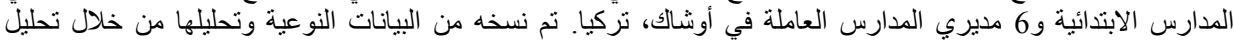

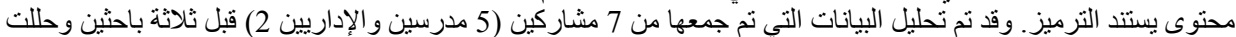

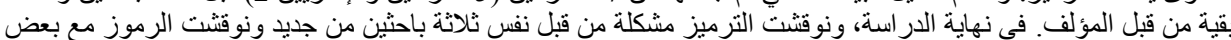

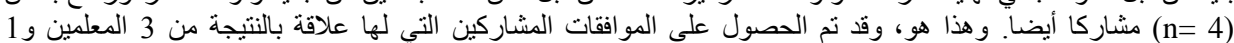

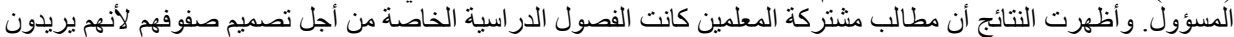

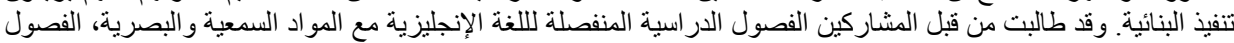

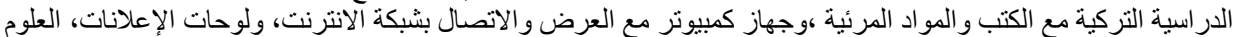

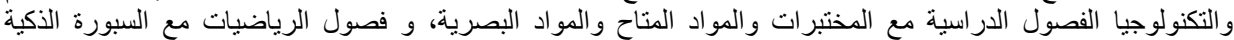
و والمستودعات واسعة، والمو اد الرياضية. الكلمات الرئيسية: المناهج البنائية، وبيئات التعلم البنائية، وجهات نظر مديري الددارس ،آراء المعلمين ، و التعلم 


\begin{abstract}
German Abstract
Effektive Lernumgebung Merkmale als Voraussetzung von konstruktivistischen Lehrplan: Lehrer Bedürfnisse und Ansichten von Schulleitern

Das Ziel dieser Studie ist Grundschullehrer und Schulleiter Ansichten über physische Lernumgebungen von Schulen, um zu bestimmen, wo Lehrer erwartet die konstruktivistische Philosophie / Konzept umzusetzen. In dieser qualitativen Studie befragten die Forscher 48 Grundschullehrer und 6 Schulverwaltung arbeiten in Usak, Türkei. Die qualitativen Daten wurden transkribiert und analysiert durch Codierung basierenden Inhaltsanalyse. Die Daten von 7 Teilnehmern gesammelt (5 Lehrer und zwei Administratoren) wurden von drei Forscher analysierten und der Rest vom Autor analysiert. Am Ende der Studie wurde problematisch Codierung durch die gleichen drei Forscher erneut diskutiert und Codes wurden mit einigen diskutiert $(n=4)$ Teilnehmern als gut. Das heißt, der Teilnehmer-Zulassungen auf die Ergebnisse im Zusammenhang wurden von drei Lehrern erhalten und 1-Administrator. Die Ergebnisse zeigten, dass der Lehrer gemeinsamen Forderungen waren Spezialklassen, um ihre Klassen zu entwerfen, weil sie Konstruktivismus implementieren möchten. Separate Englisch Sprachenunterricht mit audiovisueller Materialien; Türkisch Klassenzimmer mit Bücher, Bildmaterial, einen Computer mit Beamer und Internetanschluss, und Bulletin Boards; Wissenschaft und Technik Klassen mit Laboratorien, Einwegmaterialien und visuelle Materialien; Mathematikunterricht mit Smart Board, breiten Speicher und mathematische Materialien wurden von den Teilnehmern gefordert.
\end{abstract}

Schlüsselwörter: liste konstruktivistischen lernumgebungen, schulleiter ansichten, lehrer ansichten, lernen, lehrer

\title{
Malaysian Abstract \\ Ciri-ciri Persekitaran Pembelajaran Berkesan sebagai keperluan konstruktivis Kurikulum: Keperluan Guru dan Pandangan Pengetua Sekolah
}

Tujuan kajian ini adalah untuk menentukan pandangan guru-guru sekolah rendah dan pengetua sekolah mengenai persekitaran pembelajaran fizikal sekolah di mana guru dijangka melaksanakan falsafah / pendekatan konstruktivisme. Dalam kajian kualitatif, penyelidik menemu bual 48 orang guru sekolah rendah dan 6 pentadbir sekolah yang bekerja di Usak, Turki. Data kualitatif kemudian ditranskripsikan dan dianalisis melalui analisis kandungan berasaskan pengkodan. Data yang dikumpul dari 7 peserta ( 5 orang guru dan 2 pentadbir) dianalisis oleh tiga penyelidik dan selebihnya telah dianalisis oleh penulis. Pada akhir kajian ini, pengekodan yang bermasalah telah dibincangkan oleh tiga penyelidik dan kod telah dibincangkan dengan beberapa $(n=4)$ peserta juga. Pengesahan peserta berkaitan dengan dapatan kajian telah diperoleh daripada 3 guru dan 1 pentadbir. Dapatan kajian menunjukkan bahawa permintaan guru adalah bilik darjah khas untuk merangka kelas mereka kerana mereka mahu melaksanakan konstruktivisme. Bilik darjah Bahasa Inggeris yang berasingan dengan bahan-bahan audio-visual; Bilik Darjah Turki dengan bukubuku, bahan-bahan visual, komputer dengan projektor dan sambungan internet, dan papan buletin; Kelas Sains dan Teknologi dengan makmal, bahan pakai buang dan bahan-bahan visual; Kelas Matematik dengan papan pintar, ruang penyimpanan yang luas, dan bahan-bahan matematik antara yang telah dimintaoleh peserta.

Kata Kunci: kurikulum konstruktivis, persekitaran pembelajaran konstruktivis, pandangan guru, pandangan pengetua sekolah, pembelajaran 